\title{
Toxicity Evaluation of Pharmaceutical Wastewater to the Nile Tilapia (Oreochromis niloticus)
}

\author{
Scholastica Mnena Lan, Tam-Miette Dawari Briggs, Henry Ebele Obanya, \\ Nnamdi Henry Amaeze, Adebayo Akeem Otitoloju
}

Ecotoxicology Laboratory, Department of Zoology, University of Lagos, Lagos, Nigeria

Email: henryobanya@rocketmail.com

How to cite this paper: Lan, S.M., Briggs, T.-M.D., Obanya, H.E., Amaeze, N.H. and Otitoloju, A.A. (2021) Toxicity Evaluation of Pharmaceutical Wastewater to the Nile Tilapia (Oreochromis niloticus). Journal of Environmental Protection, 12, 296-309. https://doi.org/10.4236/jep.2021.124019

Received: March 5, 2021

Accepted: April 26, 2021

Published: April 29, 2021

\section{Copyright $\odot 2021$ by author(s) and} Scientific Research Publishing Inc. This work is licensed under the Creative Commons Attribution International License (CC BY 4.0).

http://creativecommons.org/licenses/by/4.0/

\begin{abstract}
This study assessed the levels of oxidative stress biomarkers in gills and liver, as well as the activities of transaminases in the liver of Nile tilapia (Oreochromis niloticus), exposed to pharmaceutical effluents. The pharmaceutical effluents were collected from two pharmaceutical industries in Lagos, Nigeria. The assessment of physicochemical characteristics of the effluents indicated that some parameters were not in accordance with NESREA limits. The acute toxicity studies showed that $96 \mathrm{hrLC}_{50}$ values of "effluent A" and "effluent B" were $27.0 \mathrm{ml} / \mathrm{L}$ and $18.0 \mathrm{ml} / \mathrm{L}$ respectively. The juveniles of $O$. niloticus were exposed to $1 / 100^{\text {th }}$ and $1 / 10^{\text {th }} \mathrm{LC}_{50}$ s of the two effluents for a period of 14 and 28 days. These concentrations significantly increased the level of the lipid peroxidation product, malondialdehyde. There was also inhibition of the activities of superoxide dismutase and catalase as well as significantly lower levels of reduced glutathione after 28 days. The levels of the transaminases (aspartate aminotransferase and alanine transaminase) were elevated in the liver of the fish after the exposure to the effluents. The present findings showed that the wastewater caused oxidative stress and hepatocellular damage in the fish suggesting potential ecotoxicological risks of the wastewater to aquatic organisms.
\end{abstract}

\section{Keywords}

Pharmaceutical Effluents, Oreochromis niloticus, Oxidative Stress, Transaminases

\section{Introduction}

The pharmaceutical industry has been noted as one of the major sources of ef- 
fluent discharge into aquatic ecosystems [1]. There are a few pharmaceutical companies in Nigeria of which most are located in Lagos and Ogun States and these companies discharge their wastewater into nearby creeks, rivers, and lagoons [2]. The effluents commonly known as pharmaceutical effluents are wastewater generated during drug production by these pharmaceutical industries [3]. The fate of pharmaceutical effluents in aquatic ecosystems is dependent on the physical and chemical characteristics of the individual components of the effluents and the nature of the receiving water body [4]. During wastewater treatment in sewage treatment plants (STPs), components with low adsorption coefficient tend to remain in the aqueous phase which enhances their mobility into the receiving water body [5]. Pharmaceutical effluents contain a vast number of chemicals and microorganisms depending on the drug that is being produced and are toxic to biological organisms due to the presence of salt, surfactants (detergents, emulsifiers and dispersant), ionic metals and their metal complexes, organic chemicals, biocides, unmetabolized drugs, toxic anions and microorganisms [6] [7] [8] [9]. Some of these components can combine with unsaturated fatty acids of phospholipids located in the cell membranes [10]. This leads to oxidative damage and the production of malondialdehyde and then the oxidative stress is countered by the action of antioxidative stress enzymes such as superoxide dismutase (SOD) and catalase (CAT) [11]. Results from a biochemical assay indicated that environmentally relevant concentrations of Benzo[b]fluoranthene increased aspartate aminotransferase and alanine transaminase levels in fish. Glutathione-S-transferase, superoxide dismutase and catalase were inhibited in the exposed fish, while malondialdehyde was significantly increased [12]. Several studies have reported that specific constituents of pharmaceutical effluents have deleterious effects on living organisms [13] [14]. It has been noted that the approach of investigating the effects of individual components of pharmaceutical effluents had a limitation of providing information on the effects of all components present as a mixture in the effluent [15]. Lots of research has assessed the toxicity of pharmaceutical effluents [16] [17]. It was established in a study that bacterial isolates from pharmaceutical waste water investigated revealed multi-drug resistant strains [18]. In that regard, this study investigated the acute and biochemical effects of pharmaceutical effluents on an ecotoxicologically relevant organism. The term waste water used in the study represents treated effluents collected from the discharge point before entry into the water body.

\section{Methodology}

\subsection{Pharmaceutical Effluents Collection and Physicochemical Analyses}

"Pharmaceutical effluent A" was collected from a pharmaceutical industry located at Victoria Island, Lagos, Nigeria while "Pharmaceutical effluent B" was from a pharmaceutical industry at Ikeja, Lagos, Nigeria. The physicochemical parameters of the effluents were assessed according to the methods of APHA [19]. 


\subsection{Test Fish}

Juveniles of Nile tilapia, Oreochromis niloticus (length $7.4-8.1 \mathrm{~cm}$; weight 13.3 $14.6 \mathrm{~g}$ ) were acquired from a fish farm at Ikorodu Town, Lagos and transported to the laboratory. Upon arrival, they were transferred to holding tanks and acclimatized for a week, during which they were fed twice (morning and evening) daily with Coppens fish feed following established techniques [20].

\subsection{Bioassay Procedure}

A total of 90 acclimatized juvenile Nile tilapia specimens were exposed to sub-lethal concentrations $\left(1 / 100^{\text {th }} \mathrm{LC}_{50}\right.$ and $\left.1 / 10^{\text {th }} \mathrm{LC}_{50}\right)$ of the effluents based on the results from an initial acute toxicity evaluation. The fish were divided into three groups of 30 per group for the control and effluent treatments in glass aquaria. Each test concentration along with the control was set in triplicates of 10 fish per replicate. The test media were renewed every $48 \mathrm{~h}$ to maintain the concentration and minimize oxygen stress for the duration of the exposure. Physical-chemical water parameters were monitored daily using appropriate digital instruments (Jenway). After days 14 and 28, fish samples were dissected to obtain tissues (liver and gill) required for biochemical assays. All procedures performed in studies involving the fish were in accordance with the ethical standards of the University of Lagos Committee on the use of animal subjects in scientific research.

\subsection{Determination of Oxidative Stress Enzyme Biomarkers}

The oxidative stress biomarker responses in the liver and gills of Nile tilapia evaluated after exposure to pharmaceutical effluents after the 14 and 28 days bioassay were reduced glutathione (GSH), superoxide dismutase (SOD), catalase (CAT) and lipid peroxidation (MDA). The reduced glutathione (GSH) content of liver and gill tissues as non-protein sulphydryls was estimated according to the method described by Sedlak and Lindsay [21]. Superoxide dismutase activity was determined by its ability to inhibit the auto-oxidation of epinephrine by the increase in absorbance at $480 \mathrm{~nm}$ as described by Sun and Zigma [22]. Catalase activity was determined according to Sinha et al. [23]. It was assayed colorimetrically at $620 \mathrm{~nm}$ and expressed as micromoles of hydrogen peroxide $\left(\mathrm{H}_{2} \mathrm{O}_{2}\right)$ consumed $/ \mathrm{min} / \mathrm{ml} / \mathrm{mg}$ protein at $25^{\circ} \mathrm{C}$. Malondialdehyde (MDA) an index of lipid peroxidation was determined using the method of Buege and Aust [24].

\subsection{Determination of Transaminase Enzymes Responses}

Aspartate aminotransferase (AST) and alanine transaminase (ALT) levels were determined following the methods of Reitman and Frankel [25].

\subsection{Data Analyses}

Toxicological dose-response data involving quantal response was analyzed by Probit analysis. One-way analysis of variance (ANOVA) was used to determine 
the differences $(\mathrm{p}<0.05)$ among the various groups. Difference between each treatment group and the control was determined using Duncan multiple range test at $\mathrm{p}<0.05$.

\section{Results}

\subsection{Physicocphemical Characteristics of the Pharmaceutical Effluents}

The results of the physicochemical characterization of pharmaceutical effluent A indicated that suspended solids $(90.1 \mathrm{mg} / \mathrm{L})$, nitrate $(225 \mathrm{mg} / \mathrm{L})$, sulphate $(450$ $\mathrm{mg} / \mathrm{L})$, phosphate $(164 \mathrm{mg} / \mathrm{L})$, total hardness $(600 \mathrm{mg} / \mathrm{L})$ and cobalt $(0.725$ $\mathrm{mg} / \mathrm{L})$, colour (2490 PCU), turbidity (402 NTU), alkalinity $(250 \mathrm{mg} / \mathrm{L})$ were above NESREA limits [26] (Table 1).

Table 1. Physicochemical properties of pharmaceutical effluents.

\begin{tabular}{|c|c|c|c|}
\hline Parameters & Effluent A & Effluent B & NESREA $^{\mathrm{a}}$ \\
\hline Temperature ${ }^{\circ} \mathrm{C}$ & 24.4 & 25.9 & $<40$ \\
\hline pH & 6.65 & 6.81 & $6.5-9.0$ \\
\hline $\mathrm{DO}(\mathrm{mg} / \mathrm{L})$ & 3.5 & 1.8 & - \\
\hline Conductivity $(\mu \mathrm{S} / \mathrm{cm})$ & 333.5 & 526 & 500 \\
\hline Colour (PCU) & 2490 & 100 & 3 \\
\hline Appearance & Yellow & Whitish & Clear \\
\hline Alkalinity $(\mathrm{mg} / \mathrm{L})$ & 250 & 212.5 & 200 \\
\hline Chloride & 425.4 & 63.81 & 600 \\
\hline Turbidity NTU & 402 & 102 & 5 \\
\hline Total Dissolved Solid (mg/L) & 169 & 255 & 2000 \\
\hline Total Suspended Solid (mg/L) & 90.1 & 24.5 & 30 \\
\hline Nitrate $(\mathrm{mg} / \mathrm{L})$ & 225 & 148 & 20 \\
\hline Nitrite (mg/L) & 53.4 & 42.5 & - \\
\hline Sulphates $(\mathrm{mg} / \mathrm{L})$ & 450 & 0 & 200 \\
\hline Phosphate (mg/L) & 164 & 40.5 & 5 \\
\hline Salinity (ppt) & 0.16 & 0.24 & 0.6 \\
\hline Total Hardness (mg/L) & 600 & 600 & 150 \\
\hline Sodium $(\mathrm{mg} / \mathrm{L})$ & 120 & 100 & 200 \\
\hline Magnesium (mg/L) & 200 & 150 & 200 \\
\hline Hydrogen Sulphide (mg/L) & 0.1 & 0.15 & 0.2 \\
\hline TOC \% & 4.67 & 4.51 & 10 \\
\hline $\mathrm{COD}(\mathrm{mg} / \mathrm{L})$ & 80 & 100 & 80 \\
\hline $\mathrm{BOD}(\mathrm{mg} / \mathrm{L})$ & 20 & 31 & 30 \\
\hline Oil and Grease $(\mathrm{mg} / \mathrm{L})$ & 17.1 & 11.2 & - \\
\hline Iron $(\mathrm{mg} / \mathrm{L})$ & 0.547 & 1.753 & 20 \\
\hline Lead (mg/L) & $<0.001$ & $<0.001$ & 0.05 \\
\hline Zinc (mg/L) & 0.199 & 0.594 & 1 \\
\hline Copper (mg/L) & 0.033 & 0.036 & 1.5 \\
\hline Cobalt (mg/L) & 0.724 & 0.533 & 0.5 \\
\hline Manganese (mg/L) & 0.144 & 0.226 & 5 \\
\hline
\end{tabular}

Effluent A-Pharmaceutical effluent A; Effluent B-Pharmaceutical effluent B; ${ }^{2}$ NESREA [26]. 
The results of pharmaceutical effluent B physicochemical analysis indicated colour (100), turbidity (102 NTU), nitrate $(148 \mathrm{mg} / \mathrm{L})$ and total hardness (600 $\mathrm{mg} / \mathrm{L}$ ) were higher than NESREA stipulated limits (Table 1). Equally, higher than the NESREA limits were the levels of conductivity $(526.0 \mu \mathrm{S} / \mathrm{cm})$, alkalinity $(212.50 \mathrm{mg} / \mathrm{L})$, phosphate $(40.5 \mathrm{mg} / \mathrm{L})$, cobalt $(0.533 \mathrm{mg} / \mathrm{L})$, chemical oxygen demand $(100 \mathrm{mg} / \mathrm{L})$ and biological oxygen demand $(31 \mathrm{mg} / \mathrm{L})$ (Table 1$)$.

\subsection{Acute Toxicities of the Pharmaceutical Effluents on Oreochromis niloticus}

The 96-hour lethal concentration $\left(\mathrm{LC}_{50}\right)$ of pharmaceutical effluent $\mathrm{A}$ on juvenile tilapia fish was $27.0 \mathrm{ml} / \mathrm{L}(\mathrm{V}: \mathrm{V})$ (Table 2) whereas that of pharmaceutical effluent $\mathrm{B}$ was $18.0 \mathrm{ml} / \mathrm{L}(\mathrm{V}: \mathrm{V})$ (Table 3). The fish responded to the pharmaceutical effluents in a dose-dependent manner.

\subsection{Oxidative Stress Enzymes Responses of Nile Tilapia (Oreochromis niloticus) to Pharmaceutical Effluent A}

The results of the oxidative stress biomarkers in the gill and liver are presented in Table 4. The levels of GSH in the gills from the treated groups significantly ( $p<$ $0.05)$ decreased on days 14 and 28 in relation to the control. Activities of SOD in the gills of the treated groups were significantly $(\mathrm{p}<0.05)$ lower than the control throughout the duration of exposure. $1 / 10^{\text {th }} \mathrm{LC}_{50}$ of the effluent $\mathrm{A}$ inhibited ( $\mathrm{p}<$ $0.05)$ the activities of gill CAT on days 14 and 28. The levels of MDA in the gills of the treated groups significantly significant $(p<0.05)$ increased throughout the period of exposure.

The levels of GSH in the liver of the treated groups were significantly lower $(\mathrm{p}<005)$ than the control on day 14. However, there was no significant $(\mathrm{p}>$ 005 ) between the control and the $1 / 100^{\text {th }} \mathrm{LC}_{50}$ group on day 28 . After 28 days, the activities of SOD in the liver of the treated groups were significantly $(\mathrm{p}<0.05)$ lower than the control. CAT activities in the liver of the treated groups significantly $(\mathrm{p}<0.05)$ decreased after 14 and 28 days of exposure. The sub-lethal concentrations of effluent A caused a significant $(p<0.05)$ elevation in the levels of MDA.

Table 2. Sub-lethal dose determination for pharmaceutical A after 96 hours.

\begin{tabular}{ccccccc}
\hline Effluent A & $\begin{array}{c}\mathrm{LC}_{5} \\
(\mathrm{ml} / \mathrm{L})\end{array}$ & $\begin{array}{l}\mathrm{LC}_{50} \\
(\mathrm{ml} / \mathrm{L})\end{array}$ & $\begin{array}{l}\mathrm{LC}_{95} \\
(\mathrm{ml} / \mathrm{L})\end{array}$ & $\mathrm{DF}$ & $\mathrm{SE}$ & $\begin{array}{c}\text { Equation } \\
\text { of line }\end{array}$ \\
\hline $\begin{array}{c}\text { Concentration } \\
\text { Confidence } \\
\text { Interval }\end{array}$ & 1.9 & 27.0 & 38.84 & 3 & 0.36 & $\mathrm{Y}=1.2 \mathrm{x} \pm 0.6$ \\
\hline
\end{tabular}

Table 3. Sub-lethal dose determination for pharmaceutical B after 96 hours.

\begin{tabular}{ccccccc}
\hline Effluent B & $\begin{array}{c}\mathrm{LC}_{5} \\
(\mathrm{~m} / \mathrm{L})\end{array}$ & $\begin{array}{c}\mathrm{LC}_{50} \\
(\mathrm{~m} / \mathrm{L})\end{array}$ & $\begin{array}{c}\mathrm{LC}_{95} \\
(\mathrm{~m} / \mathrm{L})\end{array}$ & $\mathrm{DF}$ & $\mathrm{SE}$ & $\begin{array}{c}\text { Equation } \\
\text { of line }\end{array}$ \\
\hline $\begin{array}{c}\text { Concentration } \\
\text { Confidence } \\
\text { Interval }\end{array}$ & 7.00 & 18.00 & 42.63 & 3 & 0.37 & $\mathrm{Y}=2 \mathrm{x} \pm 0.5$ \\
\hline
\end{tabular}


Table 4. Oxidative stress enzymes responses of the Oreochromis niloticus to pharmaceutical effluent A.

\begin{tabular}{|c|c|c|c|c|}
\hline Gills & & & & \\
\hline $\begin{array}{c}\text { Days } \\
\text { Concentrations }\end{array}$ & $\begin{array}{c}\text { GSH } \\
(\mu \mathrm{mol} / \mathrm{ml} / \mathrm{mg} \\
\text { pro })\end{array}$ & $\begin{array}{c}\text { SOD } \\
(\mu \mathrm{mol} / \mathrm{ml} / \mathrm{mg} \\
\text { pro })\end{array}$ & $\begin{array}{c}\text { CAT } \\
(\mu \mathrm{mol} / \mathrm{ml} / \mathrm{mg} \\
\text { pro })\end{array}$ & $\begin{array}{c}\text { MDA } \\
(\mu \mathrm{mol} / \mathrm{ml} / \mathrm{mg} \\
\text { pro })\end{array}$ \\
\hline \multicolumn{5}{|l|}{14 days } \\
\hline Control & $18.90 \pm 0.88$ & $4.52 \pm 0.14$ & $30.71 \pm 1.80$ & $0.78 \pm 0.10$ \\
\hline $1 / 100^{\text {th }} \mathrm{LC}_{50}$ & $16.10 \pm 0.61^{\star}$ & $3.92 \pm 0.12^{\star}$ & $26.08 \pm 1.06$ & $3.49 \pm 0.68^{\star}$ \\
\hline $1 / 10^{\text {th }} \mathrm{LC}_{50}$ & $13.99 \pm 0.30^{*}$ & $3.21 \pm 0.02^{*}$ & $23.21 \pm 1.41^{*}$ & $4.47 \pm 0.35^{*}$ \\
\hline \multicolumn{5}{|l|}{28 days } \\
\hline Control & $17.25 \pm 0.67$ & $4.62 \pm 0.36$ & $30.36 \pm 1.42$ & $0.88 \pm 0.05$ \\
\hline $1 / 100^{\text {th }} \mathrm{LC}_{50}$ & $13.79 \pm 0.85^{\star}$ & $3.06 \pm 0.05^{\star}$ & $27.83 \pm 0.75$ & $4.03 \pm 0.36^{\star}$ \\
\hline $1 / 10^{\text {th }} \mathrm{LC}_{50}$ & $11.02 \pm 0.43^{*}$ & $2.94 \pm 0.03^{*}$ & $25.55 \pm 0.50^{*}$ & $5.44 \pm 0.61^{\star}$ \\
\hline \multicolumn{5}{|l|}{ Liver } \\
\hline \multicolumn{5}{|l|}{$\begin{array}{l}\text { Days } \\
\text { Concentrations }\end{array}$} \\
\hline \multicolumn{5}{|l|}{14 days } \\
\hline Control & $15.74 \pm 0.22$ & $4.06 \pm 0.61$ & $35.54 \pm 1.15$ & $0.73 \pm 0.05$ \\
\hline $1 / 100^{\text {th }} L_{50}$ & $12.91 \pm 0.56^{*}$ & $2.69 \pm 0.32$ & $23.36 \pm 0.54^{*}$ & $2.00 \pm 0.29^{*}$ \\
\hline $1 / 10^{\text {th }} \mathrm{LC}_{50}$ & $9.82 \pm 0.49^{*}$ & $2.27 \pm 0.04^{*}$ & $22.03 \pm 0.95^{\star}$ & $4.41 \pm 0.06^{*}$ \\
\hline \multicolumn{5}{|l|}{28 days } \\
\hline Control & $16.10 \pm 1.00$ & $4.36 \pm 0.20$ & $34.12 \pm 1.07$ & $0.76 \pm 0.04$ \\
\hline $1 / 100^{\text {th }} \mathrm{LC}_{50}$ & $12.41 \pm 1.42$ & $3.17 \pm 0.41^{\star}$ & $19.32 \pm 1.20^{*}$ & $1.820 \pm 0.38^{\star}$ \\
\hline $1 / 10^{\text {th }} \mathrm{LC}_{50}$ & $9.31 \pm 0.75^{\star}$ & $1.85 \pm 0.33^{*}$ & $14.50 \pm 0.43^{*}$ & $5.69 \pm 0.34^{\star}$ \\
\hline
\end{tabular}

${ }^{\star}$ Denotes treatments that are significantly $(\mathrm{p}<0.05)$ different from the control within the same duration of exposure.

\subsection{Oxidative Stress Enzymes Responses in the Liver of Nile Tilapia (Oreochromis niloticus) to Pharmaceutical Effluent B}

The results of the oxidative stress biomarkers in the gills and liver of the fish exposed to effluent B are presented in Table 5. GSH levels in the gills of the treated groups were significantly $(\mathrm{p}<0.05)$ lower than the control after the duration of exposure. The SOD activities in the gills of the treated groups were lower than the control, however, only those in the $1 / 10^{\text {th }} \mathrm{LC}_{50}$ group were significant $(\mathrm{p}<$ $0.05)$ after 14 days of exposure. On day 28 , the SOD activities in the treatedgroups were markedly $(\mathrm{p}<0.05)$ lower than the control. CAT activities in the gills of were markedly $(\mathrm{p}<0.05)$ lower throughout the duration of the exposure. The levels of MDA in the gills of the treated groups were significantly $(\mathrm{p}<0.05)$ higher than the control throughout the period of exposure.

The GSH levels in the liver of the treated groups were significantly $(\mathrm{p}<0.05)$ lower than the control on day 28 . The activities of the SOD in the liver of the treated groups were significantly lower than the control but did not vary significantly $(\mathrm{p}>0.05)$. CAT activities of the liver of the treated groups were significantly 
Table 5. Oxidative stress enzymes responses in the liver of the Tilapia Fish (Oreochromis niloticus) to pharmaceutical effluent B.

\begin{tabular}{|c|c|c|c|c|}
\hline Gills & & & & \\
\hline $\begin{array}{c}\text { Days } \\
\text { Concentrations }\end{array}$ & $\begin{array}{c}\mathrm{GSH} \\
(\mu \mathrm{mol} / \mathrm{ml} / \mathrm{mg} \\
\text { pro })\end{array}$ & $\begin{array}{c}\text { SOD } \\
(\mu \mathrm{mol} / \mathrm{ml} / \mathrm{mg} \\
\text { pro })\end{array}$ & $\begin{array}{c}\text { CAT } \\
(\mu \mathrm{mol} / \mathrm{ml} / \mathrm{mg} \\
\text { pro })\end{array}$ & $\begin{array}{c}\mathrm{MDA} \\
(\mu \mathrm{mol} / \mathrm{ml} / \mathrm{mg} \\
\mathrm{pro})\end{array}$ \\
\hline \multicolumn{5}{|l|}{14 days } \\
\hline Control & $18.04 \pm 0.72$ & $5.76 \pm 0.616$ & $31.33 \pm 0.65$ & $0.83 \pm 0.07$ \\
\hline $1 / 100^{\text {th }} \mathrm{LC}_{50}$ & $15.09 \pm 0.60^{*}$ & $4.296 \pm 0.648$ & $27.76 \pm 0.75^{*}$ & $1.41 \pm 0.04^{*}$ \\
\hline $1 / 10^{\text {th }} \mathrm{LC}_{50}$ & $13.90 \pm 0.32^{*}$ & $2.82 \pm 0.51^{\star}$ & $26.48 \pm 0.94^{*}$ & $2.91 \pm 0.50^{*}$ \\
\hline \multicolumn{5}{|l|}{28 days } \\
\hline Control & $17.18 \pm 0.57$ & $5.28 \pm 0.33$ & $33.87 \pm 0.60$ & $0.82 \pm 0.04$ \\
\hline $1 / 100^{\text {th }} \mathrm{LC}_{50}$ & $14.49 \pm 0.77^{*}$ & $3.75 \pm 0.058^{*}$ & $26.26 \pm 1.27^{\star}$ & $1.30 \pm 0.20^{*}$ \\
\hline $1 / 10^{\text {th }} \mathrm{LC}_{50}$ & $13.50 \pm 0.39^{*}$ & $3.506 \pm 0.15^{\star}$ & $22.67 \pm 0.83^{*}$ & $2.61 \pm 0.28^{*}$ \\
\hline \multicolumn{5}{|l|}{ Liver } \\
\hline \multicolumn{5}{|l|}{ Days } \\
\hline \multicolumn{5}{|l|}{14 days } \\
\hline Control & $19.70 \pm 0.232$ & $4.10 \pm 0.07$ & $35.28 \pm 0.61$ & $0.74 \pm 0.05$ \\
\hline $1 / 100^{\text {th }} \mathrm{LC}_{50}$ & $18.85 \pm 0.90$ & $3.46 \pm 0.28$ & $28.47 \pm 1.12^{\star}$ & $1.88 \pm 0.08^{\star}$ \\
\hline $1 / 10^{\text {th }} \mathrm{LC}_{50}$ & $14.83 \pm 0.26^{*}$ & $3.82 \pm 0.52$ & $21.39 \pm 0.62^{*}$ & $2.31 \pm 0.10^{*}$ \\
\hline \multicolumn{5}{|l|}{28 days } \\
\hline Control & $21.04 \pm 0.89$ & $4.18 \pm 0.36$ & $24.47 \pm 0.23$ & $1.27 \pm 0.30$ \\
\hline $1 / 100^{\text {th }} \mathrm{LC}_{50}$ & $18.14 \pm 0.65^{\star}$ & $3.61 \pm 0.30$ & $22.82 \pm 0.87$ & $1.85 \pm 0.18^{\star}$ \\
\hline $1 / 10^{\text {th }} \mathrm{LC}_{50}$ & $15.54 \pm 0.39^{*}$ & $3.52 \pm 0.37$ & $18.82 \pm 0.65^{*}$ & $2.78 \pm 0.19^{*}$ \\
\hline
\end{tabular}

Denotes treatments that are significantly $(\mathrm{p}<0.05)$ different from the control within the same duration of exposure.

$(\mathrm{p}<0.05)$ lower than the control after 14 days of exposure. After 28 days of exposure, CAT activities in the liver of $1 / 10^{\text {th }} \mathrm{LC}_{50}$ group were significantly $(\mathrm{p}<$ $0.05)$ lower than the control whereas the activities in the liver in the $1 / 100^{\text {th }} \mathrm{LC}_{50}$ group did not markedly ( $p>0.05)$ differ from the control. The levels of MDA in the liver of the treated groups were significantly $(p<0.05)$ higher than the control throughout the period of exposure.

\subsection{Transaminase Enzymes Responses}

Figure $1 \&$ Figure 2 display the levels of transaminase enzymes in the fish exposed to sub-lethal concentrations of pharmaceutical effluent A. AST and ALT levels in the liver of the treated groups were significantly $(\mathrm{p}<0.05)$ higher than the control after 14 and 28 days. AST levels in the liver of the fish ranged from $76.27 \pm 1.02$ to $98.99 \pm 1.00 \mathrm{IU} / \mathrm{L}$ on day 14 whereas on day 28 they ranged from $74.08 \pm 0.788$ to $88.78 \pm 1.22$. ALT levels ranged from $26.78 \pm 1.24$ to $36.33 \pm$ $0.56 \mathrm{IU} / \mathrm{L}$ and $24.85 \pm 0.87$ to $34.32 \pm 1.00 \mathrm{IU} / \mathrm{L}$ on day 14 and 28 respectively. 


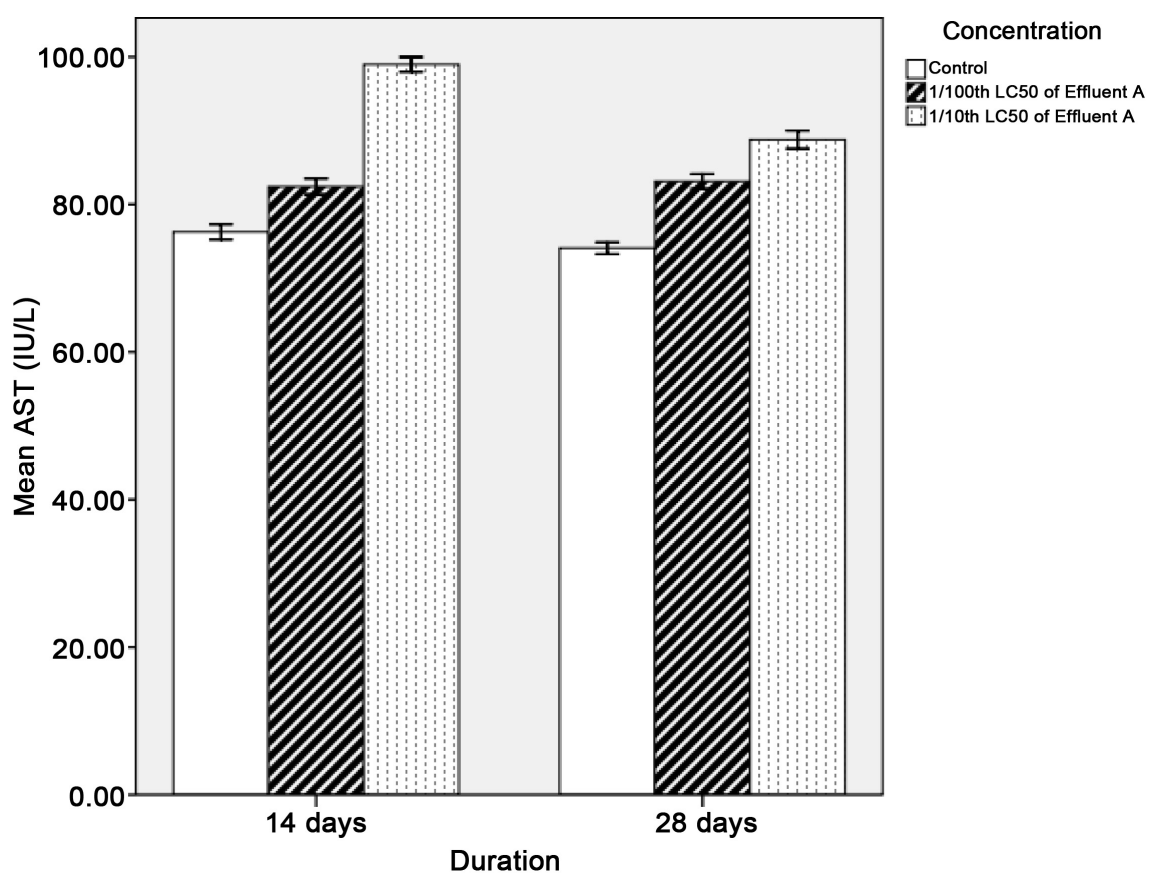

Figure 1. AST alterations in O. niloticus during chronic exposure to pharmaceutical effluent A.

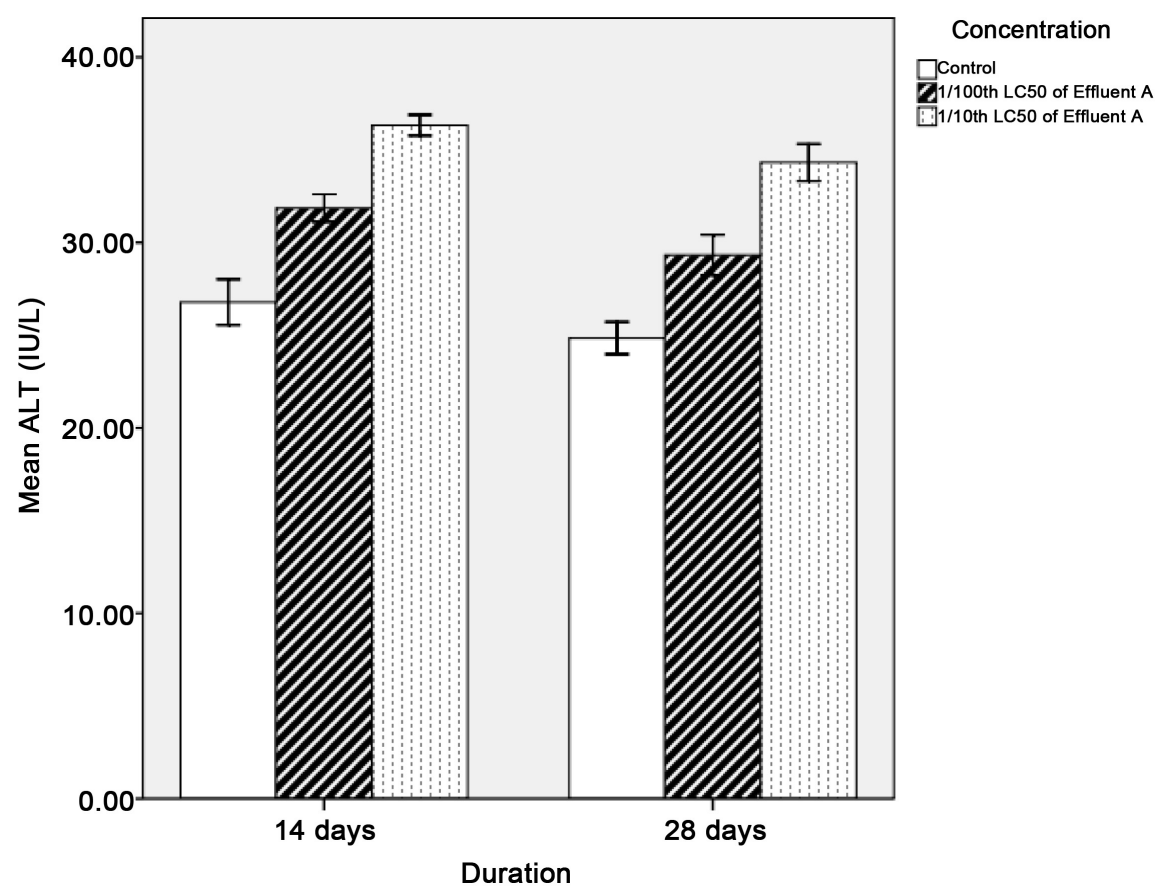

Figure 2. ALT alterations in O. niloticus during chronic exposure to pharmaceutical effluent A.

Figure 3 \& Figure 4 illustrate the levels of transaminase enzymes in the fish exposed to sub-lethal concentrations of pharmaceutical effluent B. AST and ALT levels in the liver of the effluent $B$ treated groups were significantly $(p<0.05)$ higher than the control after 14 and 28 days. The observed levels of AST in the 


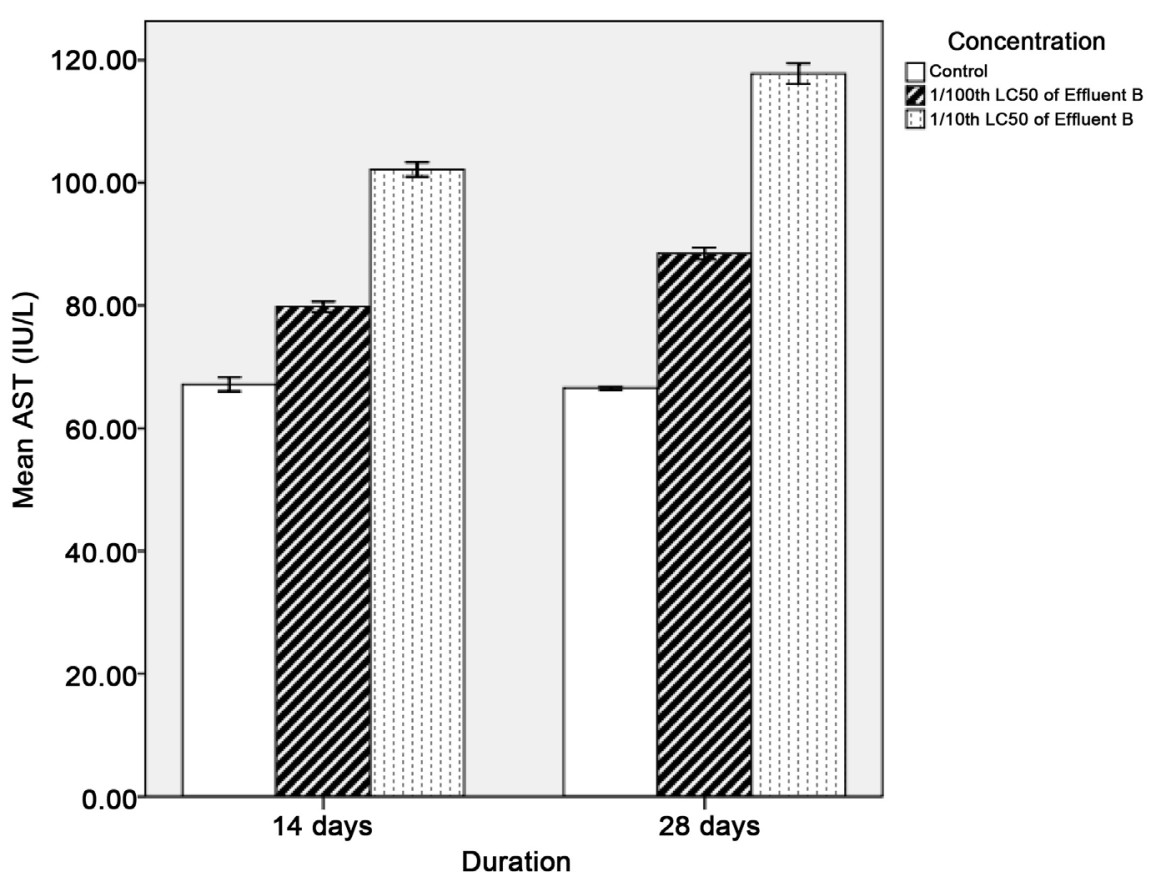

Figure 3. AST alterations in O. niloticus during chronic exposure to pharmaceutical effluent B.

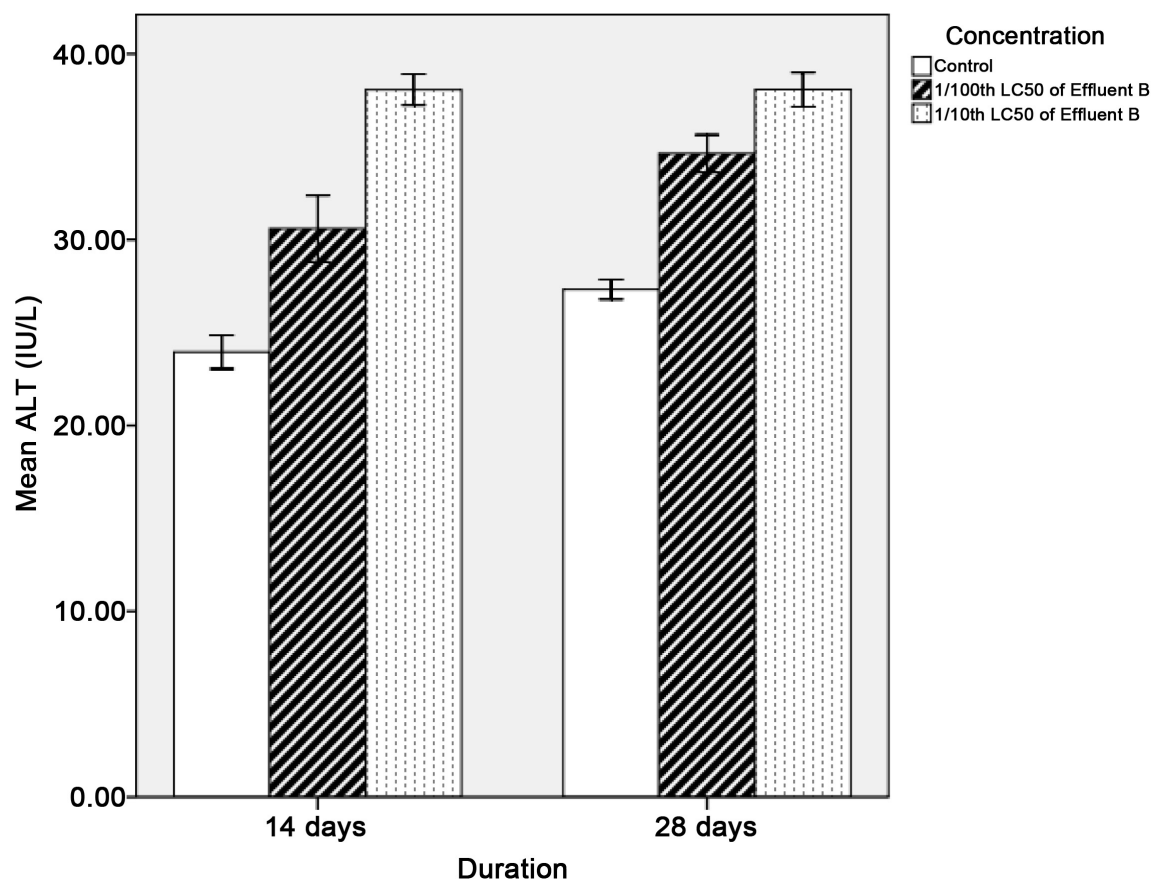

Figure 4. ALT alterations in O. niloticus during chronic exposure to pharmaceutical effluent B.

liver of the fish ranged from $67.16 \pm 1.18$ to $102.17 \pm 2.06 \mathrm{IU} / \mathrm{L}$ on day 14 . By day 28 , the levels of AST ranged from $66.57 \pm 0.26$ to $117.79 \pm 1.68 \mathrm{IU} / \mathrm{L}$. ALT levels ranged from $23.95 \pm 0.90$ to $38.07 \pm 0.83 \mathrm{IU} / \mathrm{L}$ and $27.32 \pm 0.53$ to $38.08 \pm 0.92$ IU/L on day 14 and 28 respectively. 


\section{Discussion}

The monitoring of pharmaceutical effluents before they are released into water bodies is pertinent to the protection of aquatic organisms that come in contact with their constituents. The physicochemical results of the effluents in the present study indicated that some of their parameters were not in accordance with NESREA limits. This agrees with a previous study [27] that said that the effluents were not treated properly before they were discharged into the nearby water bodies.

Specifically, the levels of nitrates and phosphates were higher than the stipulated limits. Nitrates and phosphates are important in aquatic ecosystems because they provide food for algae and plants which serve as food for fishes. Thus, an increase in nitrates and phosphates may lead to an increase in the fish population. However, if the concentrations of nitrates and phosphates increase beyond safe limits this may lead to an exponential increase in algal and plant growth (eutrophication). This phenomenon is associated with decreased levels of dissolved oxygen, thus, impairing the life functions of fishes.

The concentrations of cobalt in the effluents were also found to be higher than the limits. A previous report [28] observed that the chronic exposure of aquatic organisms to cobalt was a causal factor of growth reduction.

In this study, the biochemical responses of Nile tilapia ( $O$. niloticus) to sub-lethal concentrations of pharmaceutical effluents from two industries in the most industrialized city (Lagos) in Nigeria were also investigated. The oxidative stress biomarkers including superoxide dismutase (SOD), catalase (CAT), reduced glutathione (GSH) and malondialdehyde (MDA) as well as transaminase enzymes were monitored in Nile tilapia ( $O$. niloticus) exposed to the pharmaceutical effluents.

GSH is an endogenous antioxidant that is directly involved in the neutralization of free radicals and reactive oxygen species [29]. Reduced glutathione donates a reducing equivalent to ROS to neutralize them [30]. This reaction converts GSH to glutathione disulfide [31]. The increase in the oxidized state of glutathione in relation to the reduced state indicates oxidative stress. This implies that the depletion of GSH could sensitize the organism to the toxicity of xenobiotics that induce oxidative stress [32]. However, the elevation of GSH levels could be an adaptive mechanism to moderate oxidative stress [33]. In the present study, depletion of GSH was observed in the gills and liver of O. niloticus exposed to sub-lethal concentrations of pharmaceutical effluents. Heavy metals, one of the constituents of pharmaceutical effluents can substantially alter GSH levels in the tissues of fishes, either by causing depletion or elevation in its levels [34] [35] [36].

Catalase is an antioxidant enzyme that catalyzes the conversion of $\mathrm{H}_{2} \mathrm{O}_{2}$ into $\mathrm{O}_{2}$ and $\mathrm{H}_{2} \mathrm{O}$ [37]. Therefore, depletion of this enzyme may lead to an increase of ROS but an increase in the levels of the enzyme may be a counteractive or adaptive response to the production of ROS. CAT levels were generally lower in the 
treated fish. Furthermore, the activities of SOD in the tissues of the test organism were inhibited by the pharmaceutical effluents. SOD works with CAT to break down $\mathrm{H}_{2} \mathrm{O}_{2}$ [11]. SOD also catalyzes the dismutation of superoxide, one of the major ROS in the cell, into $\mathrm{O}_{2}$ or $\mathrm{H}_{2} \mathrm{O}_{2}$ [38].

Ultimately, there was a general significant elevation of MDA in the tissues of the test fish exposed to the pharmaceutical effluents. MDA is normally used as a lipid peroxidation marker. Lipid peroxidation occurs when free radicals or ROS oxidatively degrades lipids in cell membranes thereby causing cellular damage [10]. The high levels of MDA in the tissues of the test fish are indicative of pharmaceutical effluent-induced peroxidative damage.

Transaminase enzymes' activities are sensitive measures of hepatotoxicity and histopathologic changes in the liver [39]. AST and ALT levels were elevated in the liver of the fish exposed to the pharmaceutical effluents. A study [40] has reported that increased ALT and AST levels suggest increased proteolysis, enhanced protein catabolism and hepatocellular damage in the organism. Another set of studies [41] observed a significant increase in the levels of AST and ALT in animals treated with lead and nickel respectively. Similarly, it was reported that praziquantel, a pharmaceutical drug, caused an elevation in the levels of AST and ALT in C. gariepinus [42]. This indicates that the synergistic or additive interactions among the toxic components of the effluents may be the causal factor of the elevation in the levels of the transaminase enzymes.

\section{Conclusion}

The present findings have established that sub-lethal concentrations of pharmaceutical effluents induce biochemical effects in Nile tilapia, in terms of oxidative stress and hepatotoxicity. This raises concerns about the impact of pharmaceutical effluents on the health of fishes that inhabit aquatic environments that receive these effluents. Therefore, there is a need for proper legislation that makes it mandatory for pharmaceutical industries to effectively treat their effluents before discharging them into the environment. Their effluents should be monitored frequently in order to protect the rich biodiversity of the aquatic ecosystems. This study has shown that oxidative stress and transaminase enzymes' activities can be effectively used to monitor the effects of treated pharmaceutical effluents in aquatic organisms.

\section{Conflicts of Interest}

The authors declare no conflicts of interest regarding the publication of this paper.

\section{References}

[1] Anyakora, C., Nwaeze, K., Awodele, O., Nwadike, C., Arbabi, M. and Coker, H. (2011) Concentrations of Heavy Metals in Some Pharmaceutical Effluents in Lagos, Nigeria. Journal of Environmental Chemistry and Ecotoxicology, 3, 25-31.

[2] Obasi, A.I., Amaeze, N.H. and Osoko, D.D. (2014) Microbiological and Toxicologi- 
cal Assessment of Pharmaceutical Wastewater from the Lagos Megacity, Nigeria. Chinese Journal of Biology, 2014, Article ID: 638142. https://doi.org/10.1155/2014/638142

[3] Idris, M.A., Kolo, B.G., Garba, S.T. and Ismail, M.A. (2013) Physicochemical Analysis of Pharmaceutical Effluent and Surface Water of River Gorax in Minna, Niger State, Nigeria. Bulletin of Environment, Pharmacology and Life Sciences, 2, 45-49.

[4] Ibegbulam-Njoku, P.N., Chijioke-Osuji, C.C. and Imo, E.O. (2013) Physicochemical Characteristics and Biodegradation of Pharmaceutical Effluents. International journal of Scientific \& Engineering Research, 4, 29.

[5] Ohlenbusch, G., Kumke, M.U. and Frimmel, F.H. (2000) Sorption of Phenols to Dissolved Organic Matter Investigated by Solid Phase Microextraction. Science of the Total Environment, 253, 63-74. https://doi.org/10.1016/S0048-9697(00)00376-4

[6] Cleuvers, M. (2003) Aquatic Ecotoxicity of Pharmaceuticals Including the Assessment of Combination Effects. Toxicology Letters, 142, 185-194. https://doi.org/10.1016/S0378-4274(03)00068-7

[7] Lateef, A., Yekeen, T.A. and Ufuoma, P.E. (2007) Bacteriology and Genotoxicity of Some Pharmaceutical Wastewaters in Nigeria. International Journal of Environment and Health, 1, 551-562. https://doi.org/10.1504/IJENVH.2007.018572

[8] Akintonwa, A., Awodele, O., Olofinnade, A.T., Anyakora, C., Afolayan, G.O. and Coker, H.A.B. (2009) Assessment of the Mutagenicity of Some Pharmaceutical Effluents. American Journal of Pharmacology and Toxicology, 4, 144-150. https://doi.org/10.3844/ajptsp.2009.144.150

[9] Bakare, A.A., Okunola, A.A., Adetunji, O.A. and Jenmi, H.B. (2009) Genotoxicity Assessment of a Pharmaceutical Effluent Using Four Bioassays. Genetics and Molecular Biology, 32, 373-381. https://doi.org/10.1590/S1415-47572009000200026

[10] Chang, Y.C., Chen, C.H. and Lin, M.C. (2012) The Macronutrients in Human Milk Change after Storage in Various Containers. Pediatrics \& Neonatology, 53, 205-209. https://doi.org/10.1016/j.pedneo.2012.04.009

[11] Timbrell, J. (2000) Principles of Biochemical Toxicology. 3rd Edition, Taylor \& Francis, Abingdon-on-Thames.

[12] Obanya, H.E., Omoarukhe, A., Amaeze, N.H. and Okoroafor, C.U. (2019) Polycyclic Aromatic Hydrocarbons in Ologe Lagoon and Effects of Benzo[b]fluoranthene in African Catfish. Journal of Health and Pollution, 9, Article ID: 190605. https://doi.org/10.5696/2156-9614-9.22.190605

[13] Larsson, D.J., de Pedro, C. and Paxeus, N. (2007) Effluent from Drug Manufactures Contains Extremely High Levels of Pharmaceuticals. Journal of Hazardous Materials, 148, 751-755. https://doi.org/10.1016/j.jhazmat.2007.07.008

[14] Jones, O.A.H., Voulvoulis, N. and Lester, J.N. (2001) Human Pharmaceuticals in the Aquatic Environment a Review. Environmental Technology, 22, 1383-1394. https://doi.org/10.1080/09593330.2001.11090873

[15] Adeoye, G.O., Alimba, C.G. and Oyeleke, O.B. (2015) The Genotoxicity and Systemic Toxicity of a Pharmaceutical Effluent in Wistar Rats May Involve Oxidative Stress Induction. Toxicology Reports, 2, 1265-1272. https://doi.org/10.1016/j.toxrep.2015.09.004

[16] Babatunde, A., Bamgbola, E.P. and Oyelola, O. (2014) The Effect of Pharmaceutical Effluents on the Quality of Groundwater: A Case Study of Ikeja Industrial Area of Lagos, Nigeria. International Journal of Research in Medical and Health Sciences, 4, 1.

[17] Kumari, V. and Tripathi, A.K. (2019) Characterization of Pharmaceuticals Industri- 
al Effluent Using GC-MS and FT-IR Analyses and Defining Its Toxicity. Applied Water Science, 9, 185. https://doi.org/10.1007/s13201-019-1064-z

[18] Obayiuwana, A., Ogunjobi, A., Yang, M. and Ibekwe, M. (2018) Characterization of Bacterial Communities and Their Antibiotic Resistance Profiles in Wastewaters Obtained from Pharmaceutical Facilities in Lagos and Ogun States, Nigeria. International Journal of Environmental Research and Public Health, 15, Article No. 1365. https://doi.org/10.3390/ijerph15071365

[19] APHA (American Public Health Association) (2005) Standard Methods for the Examination of Water and Wastewater. 21st Edition, American Public Health Association, Washington DC.

[20] Amaeze, N.H., Adeyemi, R.O. and Adebesin, A.O. (2015) Oxidative Stress, Heats Shock Protein and Histopathological Effects in the Gills of African Catfish, Clarias gariepinus Induced by Bridge Runoffs. Environmental Monitoring and Assessment, 187, 172. https://doi.org/10.1007/s10661-015-4390-0

[21] Sedlak, J. and Lindsay, R.H. (1968) Estimation of Total, Protein-Bound, and NonProtein Sulfhydryl Groups in Tissue with Ellman's Reagent. Analytical Biochemistry, 25, 192-205. https://doi.org/10.1016/0003-2697(68)90092-4

[22] Sun, M. and Zigma, S. (1978) An Improved Spectrophotometer Assay of Superoxide Dismutase Based on Epinephrine Antioxidation. Analytical Biochemistry, 90, 81-89. https://doi.org/10.1016/0003-2697(78)90010-6

[23] Sinha, A.K. (1957) Colorimetric Assay of Catalase. Analytical Biochemistry, 47, 389-394. https://doi.org/10.1016/0003-2697(72)90132-7

[24] Buege, J.A. and Aust, S.D. (1978) Microsomal Lipid Peroxidation. Methods in Enzymology, 52, 302-310. https://doi.org/10.1016/S0076-6879(78)52032-6

[25] Reitman, S. and Frankel, S. (1957) A Colorimetric Method for the Determination of Serum Glutamic Oxalacetic and Glutamic Pyruvic Transaminase. American Journal of Clinical Pathology, 28, 56-63. https://doi.org/10.1093/ajcp/28.1.56

[26] NESREA (National Environmental Standards and Regulations Enforcement Agency) (2009) Maximum Permissible Limits for Wastewater Discharge. The Federal Government Press, Abuja.

[27] Olaitan, J.O., Oluwaleye, S.E., Saka, K.L. and Olabanji, D.J. (2014) Physico-Chemical Characteristics of Pharmaceutical Effluents from Sango Industrial Area, Nigeria. Bulletin of Environment, Pharmacology and Life Sciences, 3, 78-81.

[28] De Schamphelaere, K.A., Koene, J.M., Heijerick, D.G. and Janssen, C.R. (2008) Reduction of Growth and Haemolymph Ca Levels in the Freshwater Snail Lymnaea stagnalis Chronically Exposed to Cobalt. Ecotoxicology and Environmental Safety, 71, 65-70. https://doi.org/10.1016/j.ecoenv.2007.07.004

[29] Dringen, R. (2000) Metabolism and Functions of Glutathione in Brain. Progress in Neurobiology, 62, 649-671. https://doi.org/10.1016/S0301-0082(99)00060-X

[30] Jana, S.K., Dutta, M., Joshi, M., Srivastava, S., Chakravarty, B. and Chaudhury, K. (2013) 1H NMR Based Targeted Metabolite Profiling for Understanding the Complex Relationship Connecting Oxidative Stress with Endometriosis. BioMed Research International, 2013, Article ID: 329058. https://doi.org/10.1155/2013/329058

[31] Ryu, B., Himaya, S.W.A., Qian, Z.J., Lee, S.H. and Kim, S.K. (2011) Prevention of Hydrogen Peroxide-Induced Oxidative Stress in HDF Cells by Peptides Derived from Seaweed Pipefish, Syngnathus schlegeli. Peptides, 32, 639-647.

https://doi.org/10.1016/j.peptides.2011.01.009

[32] Gallagher, E.P., Hasspieler, B.M. and Di Glulio, R.T. (1992) Effects of Buthionine 
Sulfoximine and Diethyl Maleate on Glutathione Turnover in the Channel Catfish. Biochemical Pharmacology, 43, 2209-2215. https://doi.org/10.1016/0006-2952(92)90180-Q

[33] Zhang, J., Shen, H., Wang, X., Wu, J. and Xue, Y. (2004) Effects of Chronic Exposure of 2,4-Dichlorophenol on the Antioxidant System in Liver of Freshwater Fish Carassius auratus. Chemosphere, 55, 167-174. https://doi.org/10.1016/j.chemosphere.2003.10.048

[34] Kovarova, J., Celechovska, O., Kizek, R., Adam, V., Harustiakova, D. and Svobodova, Z. (2009) Effect of Metals, with Special Attention of Cd, Content of the Svitava and Svratka Rivers on Levels of Thiol Compounds in Fish Liver and Their Use as Biochemical Markers. Neuroendocrinology Letters, 30, 169-176.

[35] Cao, L., Huang, W., Liu, J., Yin, X. and Dou, S. (2010) Accumulation and Oxidative Stress Biomarkers in Japanese Flounder Larvae and Juveniles under Chronic Cadmium Exposure. Comparative Biochemistry and Physiology Part C: Toxicology \& Pharmacology, 151, 386-392. https://doi.org/10.1016/j.cbpc.2010.01.004

[36] Jia, X., Zhang, H. and Liu, X. (2011) Low Levels of Cadmium Exposure Induce DNA Damage and Oxidative Stress in the Liver of Oujiang Colored Common Carp Cyprinus carpio var. Color. Fish Physiology and Biochemistry, 37, 97-103. https://doi.org/10.1007/s10695-010-9416-5

[37] Arun, S., Thirumurugan, R., Visakan, R., Balamurugan, S., Arunachalam, V. and Subramanian, P. (2003) Optimal Analytical Conditions for Catalase in Fresh Water Prawn, Macrobrachium malcolmsonii. Biotechnic \& Histochemistry, 78, 1-4. https://doi.org/10.1080/10520290312120001

[38] Zhou, J.Y. and Prognon, P. (2006) Raw Material Enzymatic Activity Determination: A Specific Case for Validation and Comparison of Analytical Methods-The Example of Superoxide Dismutase (SOD). Journal of Pharmaceutical and Biomedical Analysis, 40, 1143-1148. https://doi.org/10.1016/j.jpba.2005.09.022

[39] Timbrel, J.A. (2009) Principles of Biochemical Toxicology, 4th Edition, Informa Healthcare, New York.

[40] Yancheva, V.S., Georgieva, E.S., Velcheva, I.G., Iliev, I.N., Vasileva, T.A., Petrova, S.T. and Stoyanova, S.G. (2014) Biomarkers in European Perch (Perca fluviatilis) Liver from a Metal-Contaminated Dam Lake. Biologia, 69, 1615-1624. https://doi.org/10.2478/s11756-014-0460-y

[41] Baghshani, H. and Shahsavani, D. (2013) Effects of Lead Acetate Exposure on Metabolic Enzyme Activities in Selected Tissues of Common Carp (Cyprinus carpio). Comparative Clinical Pathology, 22, 903-907. https://doi.org/10.1007/s00580-012-1497-3

[42] Nwani, C.D., Nnaji, M.C., Oluah, S.N., Echi, P.C., Nwamba, H.O., Ikwuagwu, O.E. and Ajima, M.N.O. (2014) Mutagenic and Physiological Responses in the Juveniles of African Catfish, Clarias gariepinus (Burchell 1822) Following Short Term Exposure to Praziquantel. Tissue and Cell, 46, 264-273.

https://doi.org/10.1016/j.tice.2014.05.011 